\title{
Finding the right tools for the job: Instrument mixes for land use and transport integration in the Netherlands
}

\author{
Marijn T. van Geet \\ University of Groningen \\ m.t.van.geet@rug.nl \\ Tim Busscher \\ University of Groningen \\ t.busscher@rug.nl
}

\author{
Sander Lenferink \\ Ratboud University \\ s.lenferink@fm.ru.nl
}

\author{
Jos Arts \\ University of Groningen \\ jos.arts@rug.nl
}

\begin{abstract}
Governments have widely established policy goals, which span the domains of land use and transport. Despite these integrated ambitions, government action often remains fragmented. This study adopts an instrumental perspective to encourage land-use and transport integration (LUTI). So far, the existing literature on this subject has adopted a single-instrument perspective and has been primarily focused on technical, rather than governance-oriented, instruments. Using a comprehensive analytical framework derived from combining policy integration and policy instrument theory, this in-depth multiple case study of the Dutch provinces of Friesland, Overijssel and North Brabant investigates how governments use a mix of policy instruments throughout the policy process to achieve LUTI in collaboration with municipalities. These instruments are compared based on how they structure interaction - i.e., the transfer of resources - across horizontal and vertical boundaries. The study finds that there is not one right tool to achieve LUTI. Instead, it is about finding the right mix of instruments, which, in line with LUTI goals, helps overcome government fragmentation by structuring interaction patterns across horizontal and vertical boundaries. Interestingly, each province adopts a unique mix of instruments that reflects a specific approach, typical to the case.
\end{abstract}

\section{Introduction}

Ever since Mitchell and Rapkin (1954) first put forward their description of the interaction between land use and transport, scholars and practitioners have made great progress in conceptualizing and operationalizing this reciprocal relationship (e.g., Bertolini, 2012; Ewing \& Cervero, 2001; Kelly, 1994; Switzer et al., 2013;

\footnotetext{
Copyright 2021 Marijn T. van Geet, Tim Busscher, Sander Lenferink \& Jos Arts
} http://dx.doi.org/10.5198/jtlu.2021.1710

ISSN: $1938-7849$ | Licensed under the Creative Commons Attribution - Noncommercial License 4.0

The Journal of Transport and Land Use is the official journal of the World Society for Transport and Land Use (WSTLUR) and is published and sponsored by the University of Minnesota Center for Transportation Studies.

\section{Article history:}

Received: December 23, 2019

Received in revised form:

September 11, 2020

Accepted: October 2, 2020

Available online: January 25,

2021 
Wegener \& Fürst, 1999). Today, land use/transport integration (LUTI) is widely acknowledged as an important requirement for developing sustainable solutions to prevent rapid growth in transport from coming at the cost of growing congestion, economic losses and further environmental degradation (IFT, 2019). Governments have also been aiming to integrate land use and transport planning to encourage sustained economic prosperity (Eddington 2006), enhance social inclusion (Farrington \& Farrington, 2005) and to improve project delivery (Heeres, Tillema, \& Arts, 2016). However, even though governments have widely adopted integrated land use and transport goals, they often struggle to bring about the needed processes of integration to attain them (e.g., Bliemer, Mulley, \& Moutou, 2016; Duffhues \& Bertolini, 2016; te Brömmelstroet \& Bertolini, 2010; UN-Habitat, 2013).

An emerging body of literature on policy design studies takes a specific interest in systematically matching goals and instruments to attain desired policy objectives (Howlett \& Lejano, 2013; Howlett, 2014a). This field of research holds that policy instrument mixes can be tailored to support policy goals in order to achieve the intended outcomes (Howlett \& Rayner, 2018). Candel and Biesbroek (2016) argued that this policy design principle also applies in the face of policy integration. They argue that policy instruments play an important role in successfully putting into practice ambitions about integration as they can help achieve "coordination and convergence between policy domains" (p. 214). Similarly, several other authors have highlighted that policy design can help in promoting policy integration (Jordan, Wurzel, \& Zito, 2005; Jordan \& Lenschow, 2010; Peters, 2018a).

Thus far, however, such an instrumental perspective on LUTI has received limited attention. The dominant share of existing literature on LUTI instruments is concerned with technical decision-support systems, such as accessibility models and transport models (Marsden \& Reardon, 2017). Only recently have scholars started to acknowledge the relevance of collaborative or governance-oriented instruments to bring about LUTI (Johansson, Tornberg, \& Fernström, 2018; Mu \& de Jong, 2016; Stead, 2016; Tornberg \& Odhage, 2018). However, in general, literature on this topic is limited to a single instrumental focus, thereby ignoring the conception that successful implementation depends on mixes of mutually supportive instruments deployed throughout the policy process ( Bemelmans-Videc, Rist, \& Vedung, 2011; Howlett \& del Rio, 2015; Stead, 2008).

This study aims to develop further an instrumental approach to LUTI by analysing the mixes of instruments governments employ throughout the policy process to promote land use/transport integration. To this end, we developed an analytical framework which combines insights from policy integration and policy design literature. The framework is used to study the processes of land use/transport integration that take place horizontally, within regional government, and vertically, between regional and local government. This subnational focus was adopted because LUTI is considered an inherently regional enterprise, as mobility issues predominantly manifest themselves at this level (Curtis, 2008; Hatzopoulou \& Miller, 2008; Marshall \& Banister, 2007; OECD, 2014; Straatemeier, 2008), and because regions are considered to be "the principal implementers of integrated land use and transport strategies" (Marshall \& Banister, 2007, p. 373).

We apply this framework to the Dutch provinces of Friesland, Overijssel and North Brabant. The Netherlands was chosen for its rich tradition in integrated planning of land use and transport (see e.g., Arts, Filarski, Jeekel, \& Toussaint, 2016). Dutch authorities have adopted numerous governance-oriented instruments to provide public goods and services jointly across administrative boundaries (OECD, 2014). Within the Dutch planning context, the role of provinces is especially interesting because they have traditionally played an integrative role in Dutch spatial planning. Rli (2016) stated that because of their tasks in promoting sustainable spatial development, regional accessibility and regional economy, Dutch provinces are the designated government tier to take the lead in LUTI. 


\section{Theoretical background}

\subsection{Understanding the "I" in LUTI}

The increased interest in integrating land use and transport planning is part of a more general trend, in which integration is adopted as a strategy to respond to the growing concern regarding the fragmented organization of the public sector. This is for example illustrated by Cejudo and Michel (2017), who established that "if the process of policy integration is successful, government action would be less fragmented." This inverse relationship between fragmentation and integration, which is fundamental in LUTI, is best understood from a historical perspective.

Traditionally, the public sector has been organized according to the Weberian model, which is characterized by a bureaucratic government, clearly delineated responsibilities and a hierarchical and sector-oriented division of tasks (Dunleavy \& Hood, 1994). Then, between the 1970s and late 1990s, the wave of New Public Management (NPM) reforms further fragmented government action as decentralization diffused the roles and responsibilities in public policy vertically between tiers of government, and disaggregation and specialization encouraged segmentation horizontally, between sectors (Peters, 2018b). These reforms caused dedicated policy domains to form lean, flat and autonomous "singlepurpose" organizational units with explicit and discrete goals and responsibilities (Cejudo \& Michel, 2017; Pollitt \& Bouckaert, 2011). Over time, these policy domains developed their own segmented conception of policy problems, appropriate solutions, ideologies and interests. Overall, these principles of decentralization, disaggregation and specialization were incrementally institutionalized through legislation, and administrative and organizational reform, thereby shaping a country's internal politics and the distribution of power, accountability and budgets. This strongly influenced public policymaking because it defined how government resources are dispersed horizontally and vertically throughout the government apparatus. Fragmentation is now inherently part of government policy and therefore difficult to reverse (Stead \& Meijers, 2009).

Even though the compartmentalized organisation of the public sector has important benefits in terms of specialization of expertise, efficiency of government responses, accountability and political representation, there are also situations in which a segmented government is less effective. For example, when dealing with interrelations between policy domains and levels of government (Peters, 2018b). This inadequacy of a fragmented government has been of growing concern as the success of any policy will often depend, at least in part, on the effects of policies from other domains (Howlett \& del Rio, 2015; Peters, 2018b). Furthermore, contemporary problems such as climate change, environmental degradation or depletion of fossil fuels, span across sectors and levels of government; their causes are embedded in different policy domains and responsibilities, and the resources to address these problems are dispersed between a variety of policy actors (Cejudo \& Michel, 2017; Christensen \& Lægreid, 2007; Jordan \& Lenschow, 2010). Integration emerged as a concept to address segmented government action in the formation and delivery of public policy by establishing inter-sectoral and multilevel relationships between interdependent policy actors (Keast, Brown, \& Mandell, 2007; Tosun \& Lang, 2017; Trein, Meyer, \& Mggetti, 2019). Conceptually, policy integration relates to a broad body of literature that has developed in different policy sectors using different terminologies such as, cooperation, coordination, joined-up government, and whole of government, which are typically used interchangeably.

To establish conceptual clarity, this study defines policy integration along four theory-based principles. First, policy integration is a strategy to overcome fragmented government action (Trein et al., 2019); a higher level of policy integration implies that government action is less fragmented (Cejudo \& Michel, 2017). Second, policy integration is a process in which policy actors collectively respond to a cross-cutting policy problems and/or give effect to a shared objective by coordinating policy action 
across policy domains and government levels. Policy integration processes can be both oriented towards formulating goals and towards developing mixes of policy instruments (Candel \& Biesbroek, 2016). Cejudo and Michel (2017) argue that integrated goals are defined collectively instead of autonomously and are incorporated into an overarching strategy so that multiple domains are united and contribute rather than undermine each other in tackling a shared policy problem more or less holistically. On instrumental level, integration is achieved when policy instruments are developed - individually and together - to meet the shared policy goals they serve consistently and to help coordinate action across policy domains. Candel \& Biesbroek (2016) acknowledge that processes of policy integration are often characterized by discrepancies or time lags between the degree of integration that is achieved on goals level and instrument level. Third, processes of integration are based on the need to establish interdependent relations as an incentive to cross administrative boundaries (Keast et al., 2007). These dependencies arise from the fact that different and specific resources - see Table 1 - need to be drawn from a wider range of policy actors to make and implement policies (Ansell, 2000; Klijn \& Koppenjan, 2016; Kooiman, 2003). Fourth, interaction - the transfer of resources - is a key mechanism in policy integration processes as it helps overcome interdependencies, thereby enhancing the capacity to achieve shared goals and solving complex policy problems (Cejudo \& Michel, 2017). Higher degrees if integration are therefore associated with higher degrees and frequencies of interaction between a greater variety of policy sectors and levels of government (Candel \& Biesbroek, 2016; Peters, 2015; Stead, Geerlings, \&Meijers, 2004).

Table 1. The five resources transferred in processes of public policy formation and implementation - based on Klijn and Koppenjan (2016)

\begin{tabular}{|ll|}
\hline Resources & Description \\
\hline Financial resources (FRs) & $\begin{array}{l}\text { FRs refer to money and budgets. FRs are needed to cover the cost of policy } \\
\text { formation and implementation. As such, FRs provide opportunities not only to } \\
\text { finance policy solutions, but also to cover the transaction costs attached to the } \\
\text { decision-making processes prior to actual implementation. }\end{array}$ \\
\hline Production resources (PRs) & $\begin{array}{l}\text { PRs are the resources needed for the actual realization of solutions, policies and } \\
\text { services. This can include, for instance, land ownership for an urban restructur- } \\
\text { ing project, a construction firm's building equipment or the necessary staff. }\end{array}$ \\
\hline Competency resources (CRs) & $\begin{array}{l}\text { CRs concern the juridical authority ("competence") to make certain decisions. } \\
\text { Examples include the authority to decide on zoning plans or to issue permits } \\
\text { for certain activities. }\end{array}$ \\
\hline Knowledge resources $(K R s)$ & $\begin{array}{l}\text { KRs are important for investigating problems and generating solutions. KRs } \\
\text { can be made available through documents or by prompting a knowledgeable } \\
\text { actor to transfer implicit knowledge in the decision-making process. }\end{array}$ \\
\hline Legitimacy resources $(L R s)$ & $\begin{array}{l}\text { LRs are a relatively vague resource which concern granting legitimacy to, or } \\
\text { withhold legitimacy from, a decision. LRs can include the support of elected } \\
\text { political bodies, the media or citizens, giving extra weight to a project or policy } \\
\text { initiative. }\end{array}$ \\
\hline
\end{tabular}

\subsection{Land use/transport integration}

In light of the above discussion, LUTI is framed as a strategy for overcoming growing concerns about fragmented government action in land use and transport (Hull, 2008). Traditionally, transport planning was a technocratic, self-contained discipline which can be characterized as siloed, line-oriented, and primarily aimed at enhancing transport system performance (Heeres, Tillema, \& Arts, 2012). Transport policies often focused on a single infrastructure mode (road, water, rail etc.) and were limited in scope 
(Banister, 2005). As a consequence of quantitative predict-and-provide thinking, transport planners were primarily focussed on meeting the increasing demand for transport through infrastructure development and expansion. Growing insights into the interrelationships and interactions between, at first, different transport modes, and later between the transport and land use systems, provoked trenchant critique of this technical rationality (Banister, 2002). Transport planning is increasingly acknowledged ideally to take into account the boundary-spanning and multi-scalar nature of transport services and mobility patterns as well as the interrelationship with land use (Arts, Hanekamp, \& Dijkstra, 2014; Arts, Hanekamp, Linssen, \& Snippe, 2016).

As a specific form of policy integration, land use/transport integration focuses on a reciprocal relationship between the land use system and the transport system (Wegener \& Fürst, 1999). In planning practice, this occurs in two different ways. The first can be regarded as land use/transport policy integration, which pertains to a strategic orientation and generally aims to "contribute to an optimum spatial organization of activities and a well-balanced transport system linking these activities in an efficient and sustainable way" (Wegener \& Fürst, 1999, p. 76). Even though the strategic orientation to LUTI is considered valuable as it may lead to a variety of social (Farrington \& Farrington, 2005; Gudmundsson et al., 2015) and economic benefits (Banister \& Berechman, 2001), the environmental argument for integration is most dominant (Banister et al., 2011; Bache et al., 2015). Reducing the need for transport and increasing the use of sustainable transport modes to reduce transport-related emissions (Bliemer et al., 2016) is highly dependent on complementary land use policy. For instance, urban density, mixed land use, neighbourhood design, proximity and distance to public transport connections successfully help create less car-dependent cities (Ewing \& Cervero, 2001; ECMT, 2002; Stead \& Marshall, 2001; van Wee et al., 2013). The second way is more operational in nature and can be regarded as land use/ transport project integration. This approach focuses on integrating infrastructure development with adjacent land use development into integrated area-development projects (Heeres et al., 2016). This type of integration is known to enhance the "overall outcomes for an area, in terms of higher quality and more sustainable results" (Heeres, 2017 p. 14). Several researchers have shown that combining transport infrastructure development with local land use development - e.g., housing, energy, nature or recreation - can improve the societal, economic and environmental revenue of projects (Arts et al., 2016, 2014; Bertolini, 2005; Elverding et al., 2008).

\subsection{Policy instruments and policy integration}

This study adopts an instrumental approach to land use/transport integration. Policy instruments are considered here the variety of deliberately devised means governments use to give effect to their policies (Howlett \& Rayner, 2007; Leroy \& Arts, 2006; Torfing, 2012). Governments usually mobilize mixes of instruments throughout the policy process to attain their objectives (Bemelmans-Videc et al., 2011; Howlett, 2014b; Howlett \& del Rio, 2015). Inspired by Lascoumes and Le Gales (2007), instruments are defined here as a particular type of institutional design, i.e., a deliberately devised set of rules which governs the interactions and behaviours of actors and organizations in order to attain a predefined outcome. By shaping interaction processes, policy instruments can have productive impacts on the results of implementation (Bressers \& O’Toole, 2005).

In general, two instrument types can be distinguished: substantive and procedural ones (Howlett, 2000). Traditionally, governments have primarily used substantive instruments to attain their goals. These command-and-control type instruments make direct use of government resources to induce the desired behaviour or prohibit certain behaviour. Examples of such substantive instruments include: subsidies, loans, grants (financial resource), regulation, licences, permitting (competence resource), advice, training and reporting (knowledge resource). Procedural instruments on the other hand act to indirectly 
"guide or steer policy processes in the direction government wishes through the manipulation of policy actors and their interrelationships" (Howlett, 2000, p.424). Procedural tools structure how the implementation process unfolds by shaping interaction and behaviour during the process of formulating and adopting policy solutions without predefining the outcomes of these processes (Howlett, 2018; Peters et al., 2018). Governments can steer interactions and interrelationships between policy actors by for instance providing information, devising overarching strategies, incorporating or excluding policy actors in decision-making, creating funding mechanisms and carrying out an administrative re-organization (Howlett, 2000, 2018).

In the context of policy integration, governments are increasingly mobilizing softer procedural instruments (Salamon, 2000). Candel and Biesbroek (2016) argued that a high degree of policy integration is generally characterized by a deployment of predominantly procedural instruments to coordinate between policy domains and levels of government. From this perspective, policy instruments can be seen as a mechanism which activates processes of interaction between networks of actors (Capano \& Howlett, 2019). Accordingly, procedural instruments can stimulate the transfer of resources to overcome interdependencies to successfully formulate and implement integrated policy solutions. These instruments can even take the form of boundary-spanning structures which oversee and address crosscutting problems as a whole (Jochim \& May, 2010). Peters et al., (2018) even suggested that procedural instruments could supplant substantive instrument interventions in the context of such network settings as procedural instruments in particular have proved important for policy integration because they structure the required cross-sectoral and multilevel interaction processes to address the fundamental links against a background of a fragmented polity.

\subsection{Policy instruments for land use/transport integration}

A variety of studies have discussed the policy instruments available to planners to better integrate land use and transport planning. Only a few of those studies have concentrated on substantive instruments; they describe how different substantial land use policy instruments (e.g., development density and mixed land use, and parking standards) and transport policy instruments (e.g., park-and-ride, cycle networks, bus rapid transit, light rail and pricing) can be combined into supportive instrument mixes (May \& Crass, 2007; May, Kelly, Shepherd, \& Jopson, 2012). Most literature on LUTI policy instruments focusses on procedural instruments. This body of research can be divided into two categories.

The first focusses on the development and use of technical decision support instruments, such as accessibility models and integrated land use/transport models, which aim to provide information to decision makers. Many such models have been developed over the years (Moeckel, Llorca Garcia, Moreno Chou, \& Okrah, 2018; Papa, Silva, te Brömmelstroet, \& Hull, 2015). The downside of these planning support systems is that they are considered to be too technical, generic, inflexible and complex (te Brömmelstroet, 2010) and there remains much debate on appropriate indictor sets. Therefore, these models are hardly ever used in practice ( Silva, Bertolini, Brömmelstroet, Milakis, \& Papa, 2017; ITF, 2019; Straatemeier, 2008).

The second group is policy instruments which aim to span boundaries between the land use and transport domains and to encourage integration processes throughout the policy process (Marsden $\&$ Reardon, 2017; Mu \& de Jong, 2016; Tornberg \& Odhage, 2018; van Geet, Lenferink, \& Leendertse, 2019). The LUTI literature describes several examples of such procedural policy instruments, e.g., establishing cross-departmental working groups (Jones \& Lucas, 2000), introducing cross-departmental budgeting schemes (Macario, Caravalho, \& Fermisson, 2005; Stead, 2008) or using planning instruments such as the Dutch "sustainable urbanization ladder" (see Duffhues \& Bertolini, 2016) and the 
Swedish "four step principle" (see Johansson et al., 2018). However, to date, research on such procedural instruments and their impact on policy integration has been rather limited and continues to be focused on individual instruments. Given that when implementing LUTI governments deploy mixes of instruments throughout the policy process to put their policies into practice, we need more insight into how mixes of procedural instruments influence LUTI, both with regard to policy formulation and implementation.

\section{$3 \quad$ Methods}

\subsection{Research design}

This study employs a multiple case study methodology (see Yin, 2003). Three Dutch cases have been compared using evidence derived from triangulating the results of desk research on government policy, in-depth interviews and focus group discussions. Such a qualitative case study approach allows for a detailed examination of how regional governments use mixes of policy instruments to facilitate interaction during processes of policy formation and implementation. A multi-case comparison design was used to strengthen analytical generalization and formulate more robust results (Yin, 2003).

The Dutch provinces of Friesland, Overijssel and North Brabant were selected for three main reasons. First, the Dutch have a long tradition of land use and transport integration as it has been a central policy objective for decades (V\&W, 1977). Second, Dutch spatial planning increasingly occurs at the regional level. Widespread endorsement of subsidiarity and decentralization principles has deconcentrated parts of the administration and decision-making on land use and transport, making Dutch sub-national governments dominant partners in land use and transport planning (Rli, 2016) - see Table 2. Third, a preliminary orientation of possible cases was carried out in cooperation with the Dutch national government officials. Overijssel, Friesland and North Brabant were identified as relevant cases, mainly because they are interesting for cross-case comparison as these provinces have been active in their attempts to integrate land use and transport using different approaches. Moreover, the cases are rooted in a similar public administrative context and the resources on land use and transport planning and development are allocated between the province and municipalities in a similar way. To allow for a more in-depth analysis, the case study focusses on land use/transport integration between provinces and municipalities; the analysis does not take into consideration the role of private, corporate, civil society, and other government stakeholders in land use and transport planning.

The process of data collection was similar for each case and was carried out in three subsequent steps. Desk research into policy documents provided input for semi-structured interviews. The interviewees were selected based on their position in the provincial organization. Our sample included public practitioners on provincial land use and transport planning, both at the policy and the project level. A total of sixteen people were interviewed: five from Friesland, four from Overijssel and seven from North Brabant (see Appendix A for a list of respondents and Appendix B for the interview guide). The interview outcomes were verified and elaborated in focus group discussions, which were held for every case. The different focus groups each comprised four to nine participants, selected on the basis of references from the interviewees. Participants were asked to comment collectively and reflect on a set of statements, which had been based on interview outcomes (see Appendix A for a list of focus group participants and Appendix $\mathrm{C}$ for the focus group setup). All the data collected was transcribed, coded and analysed using Atlas TI. Each case was analysed individually before cross-case comparisons were made. The analysis was guided by the theoretical framework following the coding scheme included in Appendix D. 
Table 2. Formal roles and responsibilities in Dutch regional land use/transport planning

\begin{tabular}{|lll|}
\hline & Municipalities & Provinces \\
\hline Land Use & - Prepare land use plans, issue permits and & - Policy on nature protection and biodiversity \\
& manage public land & - Policy on recreation, tourism and rural landscape \\
& - Manage urban and rural development & - Energy and climate, renewable energy \\
& - Housing and business development & - Agriculture and rural development \\
programmes & - Coordinate the interrelationship between regional \\
& & land use and economic development \\
& & - Coordinate municipal housing and business develop- \\
& ment programmes with a regional perspective \\
& & \\
\hline Transport & Development and maintenance of & - Development and maintenance of provincial infra- \\
& municipal infrastructure & structure \\
& & - Long-term regional strategies on transport policy \\
& & - Regional public transport network \\
&
\end{tabular}

\subsection{Analytical framework}

Figure 1 presents the analytical framework that is used to visualize and analyse the instrument mixes that are deployed in the cases to promote land use/transport integration throughout the policy process. The theory-based framework should be understood as follows: each circle represents a policy instrument. The symbols inside the circle indicate the type of resource exchange (FR - financial resources, $\mathrm{PR}$ - production resources, $\mathrm{CR}$ - competency resources, $\mathrm{KR}$ - knowledge resources, $\mathrm{LR}$ - legitimacy resources) that is promoted by the instrument and between whom these are exchanged (municipality or provincial departments). The positioning of the circle on the Y-axis reflects the direction of the observed interactions, which is either horizontal (between policy domains within the same government tier), vertical (between government tiers), or both horizontal and vertical. The positioning of the circle on the $\mathrm{X}$-axis reflects a policy instrument's position in the policy process: an instrument is either employed for the formation (strategic focus), the adoption (at the interface between strategic and operational), or the implementation (operational focus) of integrated land use/transport policy.

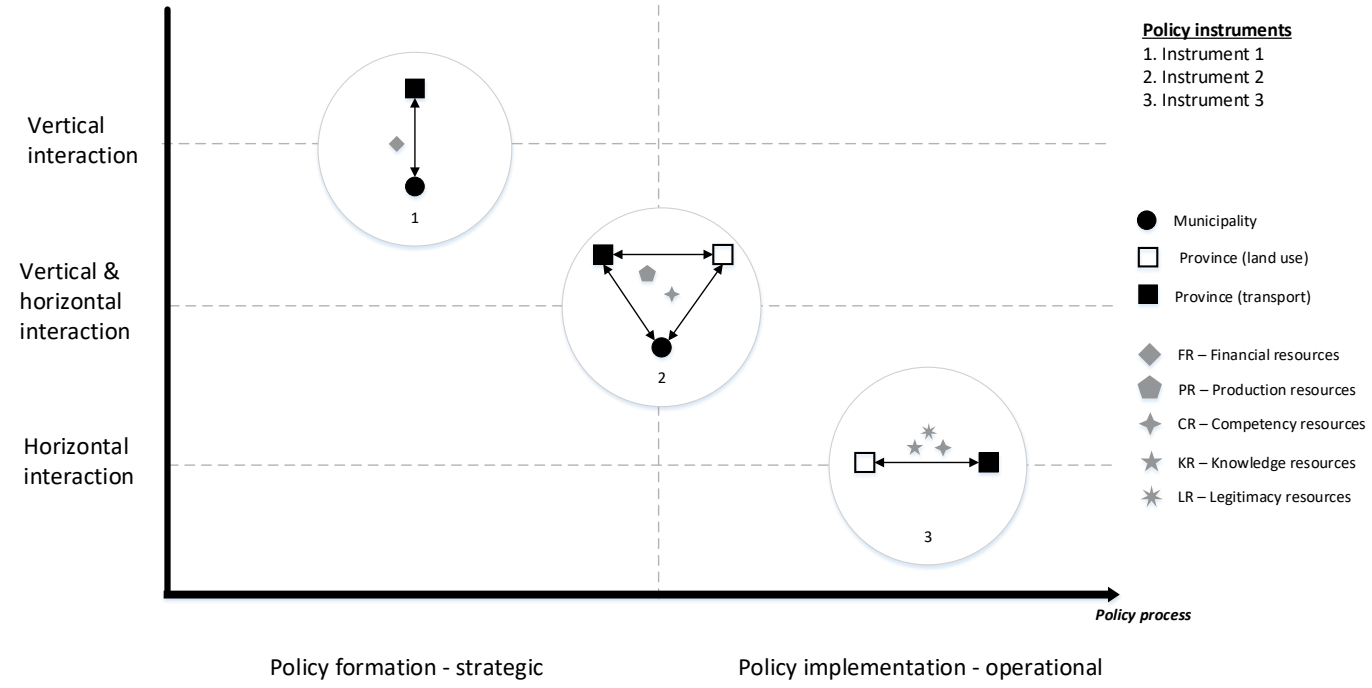

Figure 1. The analytical framework 


\section{$4 \quad$ Analysis of regional planning practice}

The case study results are presented according to the two components of the theoretical review. The first section presents the findings on how the fragmentation of the policy sector shapes Dutch regional land use and transport planning. The second section elaborates on how each case deploys a distinct mix of policy instruments throughout the planning process to structure interaction to achieve land use/transport integration.

\subsection{How resource interdependencies shape Dutch regional land use and transport planning}

Table 3 illustrates how resources associated with land use and transport planning and development are distributed horizontally, within provinces, and vertically between municipalities and provinces. Respondents expressed a variety of perspectives on how resource interdependencies influence land use/transport planning practice.

Horizontally, the unequal distribution of financial resources between the land use and transport departments was frequently highlighted. Respondent 20 stated that their department for "mobility has budget $[\ldots]$ while land use is penniless." Overall, the respondents offered numerous examples of how fragmentation of internal resources gives rise to interdependencies in achieving LUTI outcomes, triggering horizontal interaction. This quote from Respondent 3 is illustrative: "We used to have a "mobility" team and a "spatial planning" team [...] Integrating these teams has resulted in much more policy integration." Vertically, fragmentation creates interdependencies between provincial and municipal organizations. As Respondent 31 asserted: "Practically, we [the Province] are not responsible for land use planning. We are responsible for transport and mobility. We own 800 kilometres of road infrastructure [...] As such, we have to manage, maintain and invest in infrastructure. We have direct influence. But for land use planning [...] we are always dependent on others." This relationship influences how provinces and municipalities interact. For example, provinces have a key role in coordinating land use development at a regional scale, for which they may use legal ordinances. Respondents indicated that despite having this competence, provinces hesitate to use it, as - due to their interdependency - it is beneficial to them to have a good relationship with the municipalities. As such, provinces tend to adopt collaborative approaches aimed at achieving consensus: "The implementation of housing programmes lies with municipalities. The same applies to the allocation and development of business areas. In these cases we make sure to be involved at the early stages and to coordinate their plans with our own projects" (Respondent 4). 
Table 3. Fragmentation of resources on land use and transport between provincial and municipal organizations, and within provincial organizations

\begin{tabular}{|c|c|}
\hline \multicolumn{2}{|c|}{ Financial resources } \\
\hline Municipality & $\begin{array}{l}\text { Municipal budgets are first outlined in a coalition agreement and then further labelled and divided } \\
\text { between investment programmes. The available budgets and the focus of the investment programmes } \\
\text { vary between municipalities. In } 2017 \text { the average shares of municipal expenditure allocated to spatial } \\
\text { planning and housing were as follows: Friesland 5\%, Overijssel 7\% and North Brabant 9\%. For traffic } \\
\text { and transport this was: Friesland 6\%, Overijssel 5\% and North Brabant 6\% (CBS, 2016). }\end{array}$ \\
\hline Provinces & $\begin{array}{l}\text { Programme budgets are outlined in coalition agreements and later labelled specifically by the elected } \\
\text { assembly. Budgets for land use development are limited and fragmented across different investment } \\
\text { programmes. Financial resources for transport are incorporated into provincial budget programmes. This } \\
\text { programme budget is specifically allocated to different modes (car, bike and public transport) and policy } \\
\text { goals (e.g., accessibility and safety). Transferring funds within an investment programme is generally } \\
\text { easy, whereas between programmes is difficult. In } 2016 \text { the shares of provincial expenditure allocated to } \\
\text { spatial planning and housing were: Friesland } 1 \% \text {, Overijssel } 3 \% \text { and North Brabant } 2 \% \text {. For traffic and } \\
\text { transport this was: Friesland } 47 \% \text {, Overijssel } 17 \% \text { and North Brabant } 21 \% \text { (CBS, 2016). }\end{array}$ \\
\hline \multicolumn{2}{|c|}{ Production resources } \\
\hline Municipality & $\begin{array}{l}\text { Public land policy varies among municipalities. Larger municipalities in particular engage in strategic } \\
\text { land acquisition for future development of housing or business areas. Furthermore, municipalities own } \\
\text { local infrastructure and public works, and they can start legal land expropriation procedures to acquire } \\
\text { land for infrastructure and land use development if this serves a clear public interest. }\end{array}$ \\
\hline Province & $\begin{array}{l}\text { Public land policy varies among the cases. Friesland, Overijssel and Brabant avoid engaging in strategic } \\
\text { land acquisition for future housing or business development sites. They acquire land if this is required } \\
\text { to achieve policy objectives for tasks for which they are formally responsible. Provinces own regional } \\
\text { infrastructure and public works and they can start a legal land expropriation procedure to acquire land } \\
\text { for infrastructure and land use development if this serves a clear public interest. }\end{array}$ \\
\hline \multicolumn{2}{|c|}{ Competence resources } \\
\hline Municipality & $\begin{array}{l}\text { Municipalities have decision-making authority on local land use development (housing, offices and in- } \\
\text { dustry) and local infrastructure planning and development as long as this does not interfere with regional } \\
\text { or national interests. The local land use plan is their main instrument. }\end{array}$ \\
\hline Province & $\begin{array}{l}\text { Provinces have a supervisory role over municipalities from a regional perspective. To support them in } \\
\text { this task, provinces have legal instruments enabling them to direct and align municipal land use plans. In } \\
\text { domains where they have administrative responsibility (Table 2), they can use legal ordinances to imple- } \\
\text { ment policy. Provinces also have decision-making authority over regional infrastructure planning and } \\
\text { development. Provinces have legal instruments to implement infrastructure development projects which } \\
\text { automatically overrule municipality plans. }\end{array}$ \\
\hline \multicolumn{2}{|c|}{ Knowledge resources } \\
\hline Municipality & $\begin{array}{l}\text { Knowledge of land use and transport planning and development is dispersed across departments. } \\
\text { Municipalities have strategic and operational knowledge of and data on the local context, which is } \\
\text { important for LUTI at a strategic and operational level. }\end{array}$ \\
\hline Province & $\begin{array}{l}\text { Provinces have strategic knowledge and operational data at a regional scale, which is relevant for LUTI. } \\
\text { Depending on the organizational structure, the internal fragmentation of this knowledge varies per case. } \\
\text { In North Brabant, spatial planning and transport planning is conducted in separate clusters. Friesland is } \\
\text { currently organized into sectors but is incrementally adopting an organizational structure in which cross- } \\
\text { disciplinary teams work on cross-cutting policy problems. Overijssel works with a spatial planning team } \\
\text { and an accessibility team, and both teams include land use planners and transport planners. }\end{array}$ \\
\hline \multicolumn{2}{|c|}{ Legitimacy resources } \\
\hline Municipality & $\begin{array}{l}\text { Decisions are usually taken by the executive members of the municipal council (wethouders). They have } \\
\text { a sectoral mandate as their competences are linked to delineated political portfolios. Generally, land use } \\
\text { and transport are part of different portfolios managed by different executives. }\end{array}$ \\
\hline Province & $\begin{array}{l}\text { Decisions are usually taken by members of the Provincial Executive (gedeputeerden). They have a sec- } \\
\text { toral mandate as their competences are linked to delineated political portfolios. In all cases, land use and } \\
\text { transport are part of different portfolios managed by different executive members. }\end{array}$ \\
\hline
\end{tabular}




\subsection{Instrument mixes for land use and transport integration}

The results show that Friesland, Overijssel and North Brabant deploy different instrument mixes to promote LUTI. The results are presented below for each case individually: a table provides a brief description of each policy instrument used and a figure visualizes how these instruments together form a mix and how they structure interaction throughout the policy process. Furthermore, interview and focus group data set out how these policy mixes are used to achieve integrated land use and transport outcomes. A more elaborate explanation of each of the policy instruments is provided in the Appendices.

\subsubsection{Friesland - projects as a platform for integrated land use and transport development}

Table 4 describes the four policy instruments observed in Friesland. Data reveals an ongoing and widespread development towards integrated policymaking and implementation in Friesland. This trend is reflected in various ways. Foremost, Friesland has invested in developing a strong sense of community by building coalitions with municipalities, aiming to "operate as one government" (Respondent 5). Furthermore, policy integration is encouraged through a series of organizational reforms which merged policy departments: "In the past we had a provincial apparatus consisting of many cubicles, each with a person working on his or her own project. Now we are mixed [...] and I collaborate with various policy domains" (Respondent 6). Although LUTI is a prominent topic in Friesland, it only plays a marginal role during policy formation processes. Friesland's strategically-oriented instruments are used for other forms of policy integration, e.g., a sustainable energy policy is currently a major theme. Therefore, the Frisian approach to integrating land use and transport is considered as predominantly operational. Infrastructure development is used as a trigger for adjacent land use development. The motivation behind this operational focus was expressed by Respondent 8: "Our council has always stressed that whenever we develop infrastructure, we need to add value to the area [...] As such we engage with local stakeholders to develop an integrated area-development plan [...] It is a means of compensating for the impact of infrastructure development." 
Table 4. The province of Friesland's policy instruments for land use/transport integration

\begin{tabular}{|c|c|c|}
\hline Instrument name & Instrument description & Interaction pattern \\
\hline 1. The Frisian Approach & $\begin{array}{l}\text { The "Frisian Approach" is a visioning process in which the } \\
\text { province, along with } 23 \text { of the } 24 \text { municipalities, aims to } \\
\text { formulate an integrated, regional long-term environmental } \\
\text { policy strategy paper, including the potential integration of } \\
\text { municipal land use policy and provincial transport. }\end{array}$ & $\begin{array}{l}\text { Horizontal and vertical } \\
\text { transfer of knowledge and } \\
\text { legitimacy resources. }\end{array}$ \\
\hline 2. Streekwurk regions & $\begin{array}{l}\text { The province is divided into five Streekwurk regions. With- } \\
\text { in these regions, the province and municipalities collaborate } \\
\text { based on a shared regional policy agenda. The regions are } \\
\text { used by the province for making small-scale infrastructure } \\
\text { investments (e.g., bicycle infrastructure) and reaching } \\
\text { regional agreement on locations for future housing, retail or } \\
\text { business development. }\end{array}$ & $\begin{array}{l}\text { Horizontal and verti- } \\
\text { cal transfer of financial, } \\
\text { knowledge and legitimacy } \\
\text { resources. }\end{array}$ \\
\hline $\begin{array}{l}\text { 3. Integrated policy problem } \\
\text { management }\end{array}$ & $\begin{array}{l}\text { The provincial organization is divided into routine opera- } \\
\text { tions (e.g., issuance of permits, enforcement and road } \\
\text { maintenance) and the formulation and solving of cross- } \\
\text { cutting policy problems. Regarding the latter, a "Policy Issue } \\
\text { Committee" within the provincial organization translates } \\
\text { the coalition agreement into integrated policy tasks assigned } \\
\text { to cross-disciplinary teams. LUTI is not explicitly men- } \\
\text { tioned as one of the integrated policy tasks. }\end{array}$ & $\begin{array}{l}\text { Horizontal transfer of } \\
\text { financial, knowledge and } \\
\text { legitimacy resources. }\end{array}$ \\
\hline 4. Large infra projects & $\begin{array}{l}\text { All large-scale road, rail and water infrastructure develop- } \\
\text { ment projects within the province carry the label "Large } \\
\text { infra project." All these projects have a strong external orien- } \\
\text { tation as project development occurs in close collaboration } \\
\text { with the stakeholders involved (both public and private) to } \\
\text { explore possibilities to integrate infrastructure development } \\
\text { with land use developments. }\end{array}$ & $\begin{array}{l}\text { Horizontal and verti- } \\
\text { cal transfer of financial, } \\
\text { knowledge, legitimacy and } \\
\text { production resources }\end{array}$ \\
\hline
\end{tabular}

Figure 2 visualizes Friesland's policy instrument mix. Findings show that the province uses a pragmatic approach to LUTI. At the strategic level, LUTI is not well established, as Friesland's Environmental Strategy, Streekwork regions and integrated policy problem management focuses on other policy topics. This leaves unused potential in the existing strategic instruments for including LUTI. Respondents indicated that Friesland's success at achieving LUTI at the operational level results from a large-scale infrastructure development programme for which the council ordered the structural adoption of an integrative approach. Consequently, infrastructure development has been the key driver for finding opportunities for combined land use and infrastructure development. Friesland has been successful in developing these integrated land use and transport development projects. Our analysis reveals, however, that these infrastructure projects are not embedded into a wider strategic policy framework. This creates a danger that project delivery will become a goal in itself and become disconnected from any strategic foundation. 


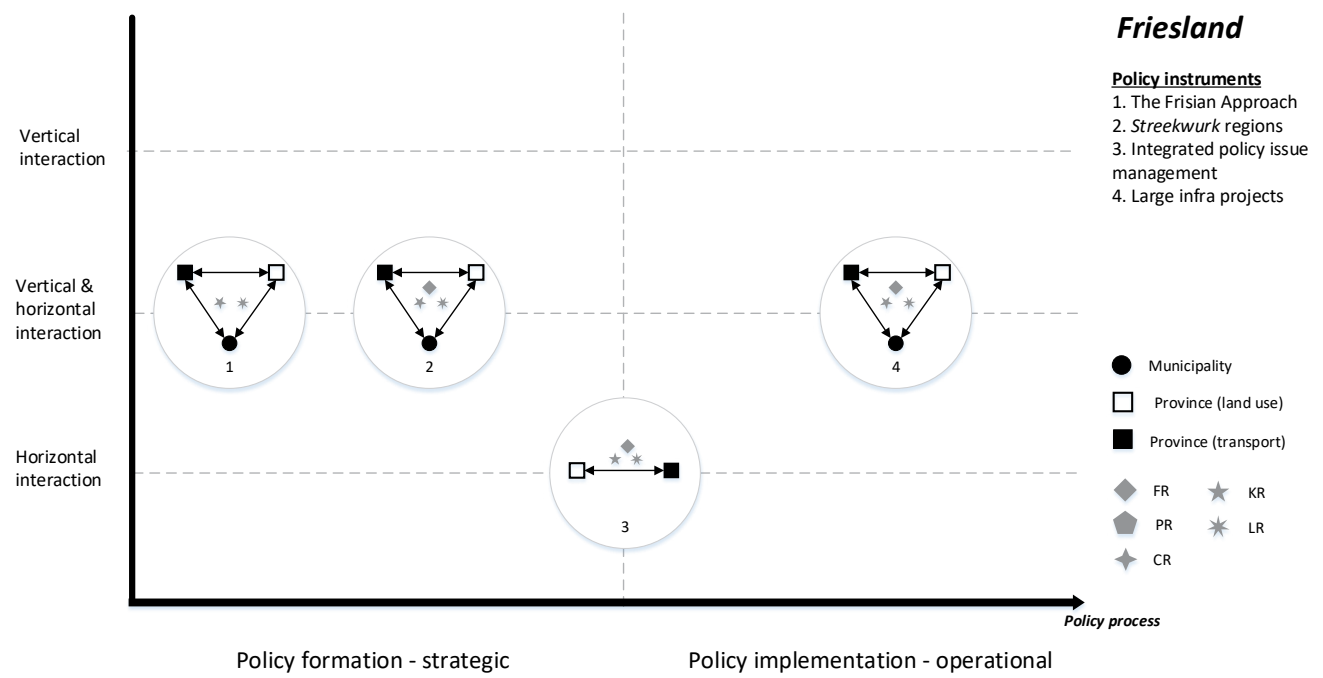

Figure 2. The province of Friesland's policy mix for land use/transport integration

\subsubsection{Overijssel - front-end focussed legal approach to land use/transport integration}

Table 5 presents the six instruments the province of Overijssel uses for integrating the planning of land use and transport. The results indicate that Overijssel's past experience in integrated spatial planning, during the implementation of the 2009 integrated environmental strategy, has benefited Overijssel in bringing about LUTI. This benefit is reflected in the close collaboration developed with municipalities on land use and transport planning: "We have a long-established tradition in front-end collaboration [...] As a result, we hardly need to use our more directive implementation instruments" (Respondent 1). Moreover, Overijssel has established a strong intra-organizational link between land use and transport at both the strategic and operational level: "The interrelation of urban dynamic and its interconnecting infrastructure network is an important planning principle [...] Infrastructure developments should be approached as integrated area-development projects" (Overijssel, 2017, pp. 99 \& 115). Overijssel's instrument mix is characterized by front-end collaboration and a legal orientation. This legal orientation is reflected in two ways. First, there is a sharp focus on formal administrative responsibilities when engaging in collaboration. As Respondent 1 put it: "we are open for collaboration if there is a clear provincial interest involved." Second, Overijssel is the only one of the three provinces to use a legal ordinance to implement LUTI. In addition to these findings, interviewees commonly expressed the principal role of early involvement of public and private stakeholders at both the policy and the project level as "shared policy goals make it easy to collaborate" (Respondent 1). 
Table 5. The province of Overijssel's policy instruments for land use/transport integration

\begin{tabular}{|c|c|c|}
\hline Instrument name & Instrument description & Interaction pattern \\
\hline $\begin{array}{l}\text { 1. Overijssel Environmental } \\
\text { Strategy }\end{array}$ & $\begin{array}{l}\text { Overijssel used its revision of the } 2009 \text { Environmental Strat- } \\
\text { egy as a way to re-establish and further develop integrated } \\
\text { policy goals in collaboration with municipalities. Existing } \\
\text { LUTI ambitions are further developed in a supplementary, } \\
\text { economically oriented, strategic network vision on the } \\
\text { integration between transport networks and the land use } \\
\text { system. }\end{array}$ & $\begin{array}{l}\text { Horizontal and vertical } \\
\text { transfer of knowl- } \\
\text { edge and legitimacy } \\
\text { resources. }\end{array}$ \\
\hline 2. Regional development agenda & $\begin{array}{l}\text { Overijssel shares a regional development agenda on land use } \\
\text { and transport with the Dutch national government, which } \\
\text { is used to obtain large national infrastructure development } \\
\text { funds. The province and municipalities collectively formu- } \\
\text { late key regional policy challenges for Overijssel which they } \\
\text { want to address in cooperation with the national govern- } \\
\text { ment. }\end{array}$ & $\begin{array}{l}\text { Horizontal and vertical } \\
\text { transfer of knowl- } \\
\text { edge and legitimacy } \\
\text { resources. }\end{array}$ \\
\hline 3. Environmental ordinance & $\begin{array}{l}\text { LUTI policy as defined in the provincial environmental } \\
\text { strategy is partly implemented by means of an area-specific } \\
\text { environmental ordinance. This ordinance explicitly consid- } \\
\text { ers the land use system and transport system as intercon- } \\
\text { nected systems. Subsequently, the ordinance incorporates } \\
\text { multiple main planning principles to promote LUTI at the } \\
\text { strategic and operational level. }\end{array}$ & $\begin{array}{l}\text { Vertical transfer of } \\
\text { competency resources. }\end{array}$ \\
\hline 4. Front-end collaboration & $\begin{array}{l}\text { Front-end collaboration encourages interaction with munic- } \\
\text { ipalities in the early stages of policy and planning develop- } \\
\text { ment to explore and subsequently benefit from integration } \\
\text { opportunities. The instrument is widely institutionalized in } \\
\text { the organization and is important for achieving LUTI. }\end{array}$ & $\begin{array}{l}\text { Horizontal and vertical } \\
\text { transfer of competency, } \\
\text { knowledge and legiti- } \\
\text { macy resources. }\end{array}$ \\
\hline $\begin{array}{l}\text { 5. Spatial planning and } \\
\text { accessibility teams }\end{array}$ & $\begin{array}{l}\text { Overijssel has integrated its spatial and transport planning } \\
\text { departments into two spatial planning and accessibility } \\
\text { teams. The Strategy Team is responsible for the formation of } \\
\text { LUTI policy. The Adoption and Execution Team is respon- } \\
\text { sible for policy implementation. }\end{array}$ & $\begin{array}{l}\text { Horizontal transfer of } \\
\text { knowledge resources. }\end{array}$ \\
\hline 6. Multi-project programmes & $\begin{array}{l}\text { Multi-project programmes are used to integrate land } \\
\text { use and infrastructure development. These programmes } \\
\text { encompass a combination of land use and infrastructure de- } \\
\text { velopment projects which are interrelated through a shared } \\
\text { programme objective. }\end{array}$ & $\begin{array}{l}\text { Horizontal and vertical } \\
\text { transfer of knowledge } \\
\text { and financial resources. }\end{array}$ \\
\hline
\end{tabular}

Figure 3 presents Overijssel's instrument mix for bringing about LUTI. It illustrates that Overijssel emphasizes integration at the interface between policy formation and implementation. Respondents indicate that the three instruments positioned at this interface have helped firmly establish LUTI principles at both the strategic and the operational level. The environmental ordinance includes strategic LUTI-oriented planning principles and renders them into area-specific ordinances which translate these principles to the operational level. Front-end collaboration is applied at both the strategic level, during policy formation, and the operational level, during project development. This collaboration allows the province to incorporate LUTI principles during the early stages of policy and project decisionmaking. Knowledge transfer in spatial planning and accessibility teams is important for defining integrated regional land use/transport policy goals in the Overijssel Environmental Strategy. These teams also work on project delivery with the ambition of integrating new infrastructure in the existing spatial context. Multi-project programmes are used to facilitate such area-oriented project development. The 
programmes structure the transfer of financial resources. Instruments 3 and 4 reflect Overijssel's more formal, coercive and legal approach to achieving LUTI. Through these instruments, Overijssel uses its legal coordinative powers to achieve LUTI goals.

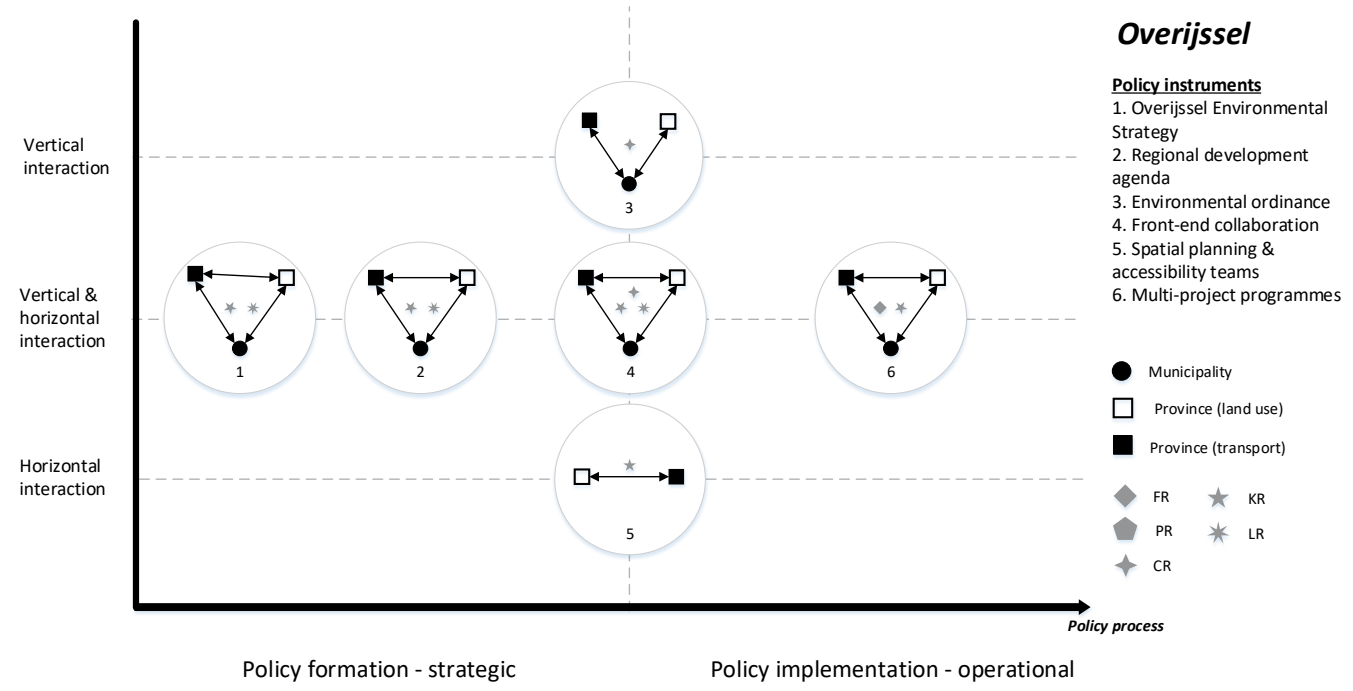

Figure 3. The province of Overijssel's policy mix for land use/transport integration

\subsubsection{North Brabant - setting land use/transport integration in informal networks}

Table 6 provides an overview of the seven instruments used by Brabant to achieve LUTI. Brabant emphasizes the importance of strong ties with municipalities to achieve land use and transport integration. Interviewees have widely confirmed that LUTI requires inter and intra-organizational interaction to overcome resource interdependencies. Discussing operational LUTI, Respondent 11 reflected on these interdependencies by stressing the importance of using "the front-end of your project well: this is where you invest in relationships [...] At later stages of the project you will enjoy the benefits of avoiding legal procedures." At a more strategic level, Brabant is characterized by close cooperation between municipal and provincial government executives; Respondent 22 suggested that it "might be typical for Brabant $[\ldots]$ to organize large-scale, strategic administrative meetings between government executives to talk about the major policy issues." At both the strategic and the operational level, Brabant invests in developing a large variety of inter and intra-organizational partnerships. Within these partnerships, the province emphasises "an informal climate for collaboration" (Respondent 14). 
Table 6. The province of North Brabant's policy instruments for land use/transport integration

\begin{tabular}{|c|c|c|}
\hline Instrument name & Instrument description & Interaction pattern \\
\hline 1. Brabant Environmental Strategy & $\begin{array}{l}\text { North Brabant has formulated an integrated environmental } \\
\text { strategy based on an inclusive visioning process. During this } \\
\text { process, many different formal and informal sessions were } \\
\text { organized with public and private stakeholders, including } \\
\text { municipalities. This strategy specifically integrates existing } \\
\text { sectoral policies on spatial planning and mobility. }\end{array}$ & $\begin{array}{l}\text { Horizontal and verti- } \\
\text { cal transfer of knowl- } \\
\text { edge and legitimacy } \\
\text { resources. }\end{array}$ \\
\hline 2. Concern strategy & $\begin{array}{l}\text { The concern strategy, which links to the Brabant Environ- } \\
\text { mental Strategy, is a strategic policy agenda at the provincial } \\
\text { management level, supported by the directors of the various } \\
\text { organizational clusters. LUTI is one of the issues on the } \\
\text { agenda. }\end{array}$ & $\begin{array}{l}\text { Horizontal transfer of } \\
\text { knowledge and legiti- } \\
\text { macy resources. }\end{array}$ \\
\hline 3. Area-oriented policy approach & $\begin{array}{l}\text { The area-oriented policy approach deals with the formula- } \\
\text { tion of shared, cross-cutting policy problems from a regional } \\
\text { perspective, taking the area as an integrated framework. } \\
\text { Depending on the scope and the location of the problem, } \\
\text { different actor networks are involved. }\end{array}$ & $\begin{array}{l}\text { Horizontal and verti- } \\
\text { cal transfer of knowl- } \\
\text { edge, legitimacy and } \\
\text { financial resources. }\end{array}$ \\
\hline 4. BrabantCity & $\begin{array}{l}\text { BrabantCity is an informal collaborative network which } \\
\text { includes the province and its five largest cities. It started in } \\
2000 \text {. The network develops a shared strategic agenda and } \\
\text { an executive agenda in which LUTI is one of the key top- } \\
\text { ics. Informal thematic meetings are periodically organized } \\
\text { between the municipal and provincial executives concerned. }\end{array}$ & $\begin{array}{l}\text { Horizontal and verti- } \\
\text { cal transfer of knowl- } \\
\text { edge and legitimacy } \\
\text { resources. }\end{array}$ \\
\hline 5. Regional development days & $\begin{array}{l}\text { Biannually, North Brabant organizes regional development } \\
\text { days for integrating regional land use and transport deci- } \\
\text { sion making. These days consist of two rounds. The first } \\
\text { round has a strong operational focus and aims to align and } \\
\text { prioritize programmed infrastructure and land use develop- } \\
\text { ments. Round two is strategic and aims at developing a } \\
\text { regional policy agenda for integrated land use and transport. } \\
\text { Development days are organized for the four North Brabant } \\
\text { regions: West, Middle, Northeast, and Southeast. }\end{array}$ & $\begin{array}{l}\text { Horizontal and verti- } \\
\text { cal transfer of knowl- } \\
\text { edge and legitimacy } \\
\text { resources. }\end{array}$ \\
\hline 6. Area-oriented project delivery & $\begin{array}{l}\text { North Brabant has adopted an area-oriented approach for } \\
\text { its latest infrastructure development projects. This approach } \\
\text { implies front-end involvement of stakeholders aiming to use } \\
\text { infrastructure development plans to kick start adjacent land } \\
\text { use developments. }\end{array}$ & $\begin{array}{l}\text { Horizontal and verti- } \\
\text { cal transfer of knowl- } \\
\text { edge, financial and } \\
\text { legitimacy resources. }\end{array}$ \\
\hline 7. Flocking & $\begin{array}{l}\text { Maintenance of provincial infrastructure is set out in } \\
\text { long-term programmes spanning multiple electoral cycles. } \\
\text { Flocking describes the intra-organizational process of find- } \\
\text { ing possible synergies between these operational infrastruc- } \\
\text { ture programmes and other, land-use oriented provincial } \\
\text { programmes (e.g., energy, nature and sustainability). }\end{array}$ & $\begin{array}{l}\text { Horizontal transfer of } \\
\text { knowledge resources. }\end{array}$ \\
\hline
\end{tabular}

Figure 4 illustrates that North Brabant's policy mix is characterized by establishing high-frequency and high-variety horizontal and vertical interactions throughout the policy process. Respondents reported that instruments predominantly facilitated the transfer of knowledge and legitimacy resources to explore shared objectives and obtain the required legitimacy resources to further pursue these objectives. Financial resources come into play when these shared objectives are translated into specific programmes or projects. Respondents stressed that LUTI is well-established in Brabant, at both the strategic and the 
operational levels. At the strategic level there is a LUTI-oriented strategic regional policy agenda supported by provincial and municipal executives. This shared agenda has proved to be a powerful tool to align the focus of all strategically-oriented instruments as well as to lobby for investment funds from the Dutch national government and the European Union. Regional development days are organised for linking policy formation and implementation, by interrelating and aligning programmed provincial and municipal land use and transport developments, and by reflecting on how these developments link to shared regional policy objectives. At the operational level, multiple instruments aim at integrating land use and transport by promoting the exchange of knowledge, legitimacy and financial resources. Integration at the operational level is strongly driven by the ambition to give impetus to the project area to stimulate successful project delivery or to find efficiencies in infrastructure maintenance programmes. More generally, respondents emphasized that North Brabant's instrument mix is successful in finding and pursuing common opportunities for LUTI as a result of short, informal communication lines and close involvement of municipal and provincial executives. Despite this agility, the instrument mix also remains rather opportunistic, as outcomes are strongly shaped by negotiations. This makes the transport sector a dominant theme, as the land use sector is in a more vulnerable position.

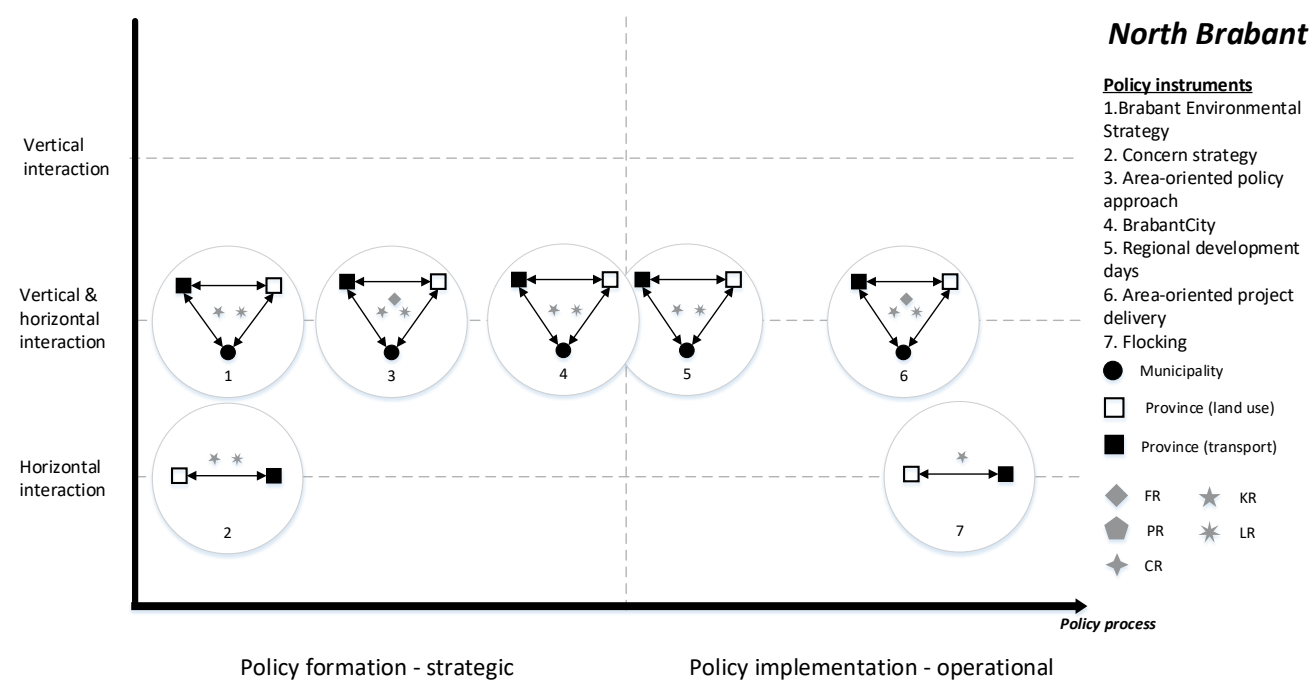

Figure 4. The province of North Brabant's policy mix for land use/transport integration

\section{$5 \quad$ Discussion and conclusion}

This article set out to develop an instrumental approach to land use/transport integration. To achieve this objective, a multiple case study was performed to compare how Dutch regional governments use mixes of policy instruments throughout the policy process to achieve LUTI. As mentioned in the literature review, fragmentation of the public sector has dispersed financial, production, competency, knowledge and legitimacy resources on land use and transport across tiers of government and within each of these tiers. The success of LUTI depends on the extent to which policy actors successfully transfer these resources to overcome their interdependencies to formulate and implement integrated land use and transport solutions. The results are discussed below and conclusions are drawn in line with the theoretical framework underlying this study. 


\subsection{Overcoming fragmented land use and transport planning}

The negative effect of government fragmentation on policy integration is widely discussed in public management literature. Likewise, within the field of transport planning, multiple studies have underlined that fragmentation is a key barrier for LUTI (Hull, 2010; UN-Habitat, 2013). Inspired by Pfeffer and Salancik (2003) and Poppelaars (2007), this study adopted a resource perspective to address this issue. It was found that in line with the segmentation of roles and responsibilities, government resources on land use and transport planning are dispersed between and within levels of government. The cases show that pursuing LUTI creates resource interdependencies as no single actor possesses all the required resources. To overcome these interdependencies, Friesland, Overijssel and North Brabant engage in horizontal and vertical interaction processes. They use mixes of policy instruments to structure these patterns of interaction throughout the policy process.

\subsection{Policy instrument mixes for developing and delivering integrated land use/transport policy}

This study identified a total of seventeen policy instruments used to promote LUTI. Many of these instruments have been reported in previous studies, such as the use of broad strategic concepts (Marshall $\&$ Banister, 2007), regional planning structures or umbrella organizations (Macario et al., 2005; Marsden \& May, 2006; Mu \& de Jong, 2016; UN-Habitat, 2013), integrated transport projects (Heeres et al., 2012; Lahdenperä, 2012; Lenferink, Tillema, \& Arts, 2013) and cross-sectoral teams (Geerlings $\&$ Stead, 2003). Furthermore, it stands out that this study exclusively identified governance-oriented procedural instruments. As such, our findings are in line with Peters et al. (2018) who argued that procedural policy instruments, rather than substantive instruments, are appropriate in the context of interdependencies because they indirectly shape policy outcomes by influencing how policy actors interact in policy processes. Interestingly, it was found that none of the cases use technical decision-support instruments to promote LUTI. This finding mirrors the outcomes of earlier studies which found that despite the large body of literature, these technical instruments (e.g., accessibility and land use/transport models) are seldom used in practice (ITF, 2019; Moeckel et al., 2018; Papa et al., 2015).

As addressed in the literature review, existing research on LUTI has predominantly focused on a single policy instrument. This study finds, however, that governments deploy mixes of complementary policy instruments throughout the policy process to promote LUTI. Even though the specific configuration of instruments differs per case, all mixes highlight the importance of complementarity between the different instruments for achieving LUTI. For example, all three mixes include some form of comprehensive strategic spatial plan which is further operationalized in a shared regional policy agenda or other regional planning structure. It can be concluded that these regional planning instruments play a crucial role in the integration of provincial and municipal land use and transport policies and in the operationalization of these policies into specific infrastructure investments and land use interventions. Another interesting finding relates to the different policy instruments found at the interface of the formation and implementation phases (see Figures 2-4). Outcomes show that these are important for operationalizing integrated land use/transport policy, as well as preparing for land use/transport project integration in the policy implementation phase. These outcomes illustrate, in line with Rayner and Howlett (2009), that policy formation and implementation instruments strongly interrelate and should be considered together in a single mix. Furthermore, it underlines previous studies which highlighted that land use/transport integration requires attention and instruments throughout the policy process (Macario et al., 2005; van Geet, Lenferink, \& Arts, 2019).

Comparing the three policy mixes found, it is striking that each mix is unique and reflects a distinct 
approach to land use/transport integration. Whereas the Province of Friesland pursues a pragmatic and project-oriented approach to LUTI, Overijssel's style is directed at achieving both policy and project integration but in a more formalized, hierarchical manner which heavily relies on the use of competency resources. Alternatively, North Brabant has the same combined policy and project focus but aims to achieve LUTI by fostering a high intensity of informal interaction throughout the policy process. These differences between the cases underline that there is no silver bullet to achieving LUTI. Rather, these outcomes confirm what is described in earlier studies: that instrument mixes need to be tailored to fit the contextual setting in which they operate (Howlett \& Rayner, 2004; Lieu et al., 2018; Rogge \& Reichardt, 2016).

\subsection{Patterns of resource transfer in land use/transport integration}

To provide a more in-depth understanding of how policy instruments structure interaction to achieve LUTI, this study qualitatively compared each instrument in terms of interaction - i.e., the horizontal and vertical transfer of financial, production, competency, knowledge and legitimacy resources. We found that most policy instruments combine simultaneous processes of horizontal and vertical interaction. These outcomes are likely to be related to the horizontal and vertical fragmentation of land use and transport resources observed between provincial departments and between municipalities and provinces. Furthermore, it is striking that knowledge and legitimacy resources are most frequently transferred, generally in combination with one another. This illustrates the general importance of information flows and shared decision-making throughout the policy process. Furthermore, the opposing use of competency resources between cases stands out. While Overijssel shows that competency is a powerful resource for achieving LUTI, the other cases deliberately avoided using it because of its potential for negatively affecting their relationships with municipalities. In addition, the results suggest that the transfer of production resources was not found in any of the instruments. This could be explained by Dutch legislation which defines specific land expropriation procedures.

More generally, these findings acknowledge, in line with Pfeffer and Salanciks's (2003) and Poppelaars's (2007) conceptions, that resource dependency is a key driver for interaction. The fragmentation of land use and transport resources creates interdependencies and a need to collaborate across horizontal and vertical boundaries. Recently, a number of scholars have underlined the need to adopt a more governance-oriented approach to transport planning (Marsden \& Reardon, 2017; Mu \& de Jong, 2016; Tornberg \& Odhage, 2018). These findings once more stress the importance of research on this topic.

\subsection{Achieving land use/transport integration: finding the right instrument mix for the job}

Taken together, these results help to develop an instrumental approach to LUTI. Such an instrumental approach could be an effective option to overcome government fragmentation in addition to existing institutional approaches to LUTI. While institutional approaches address fragmentation by removing institutional barriers, this instrumental perspective is characterized by overcoming fragmentation through interaction. Stead \& Meijers (2009) are among those who have highlighted the persistence of administrative boundaries, suggesting that overcoming fragmentation could be a more efficient strategy than resolving fragmentation.

This comparative case study on Dutch regional planning shows that governments use mixes of policy instruments throughout the policy process to pursue land use/transport integration. In general, we conclude that there is not one right tool for LUTI. Instead, it is about finding the right mix of in- 
struments which, in line with LUTI-goals, helps overcome the fragmentation of resources throughout the planning process by structuring interaction patterns across horizontal and vertical boundaries. More specifically, the fragmented organisation of the public sector determines how government resources on land use and transport are distributed between and within tiers of government. This drives Friesland, Overijssel and North Brabant to interact in policy networks for the development and delivery of integrated land use/transport policies and projects. To structure these interaction patterns, each province adopts a unique mix of policy instruments: these mixes primarily consist of procedural instruments. Throughout the policy process, interaction predominantly entails the simultaneous transfer of knowledge and legitimacy resources which reflects the importance of information flows and shared decision making in the LUTI process. Furthermore, competency resources can be used to construct powerful and coercive policy instruments for LUTI. Nevertheless, cross-case comparison shows that this resource is not necessary to achieve LUTI.

\subsection{Implications, limitations and directions for future research}

Overall, this study developed a further understanding of how policy instruments can play a central role in achieving LUTI. Its outcomes provide insight into how mixes of mutually supportive instruments can shape the interaction processes that encourage integration. The study findings suggest that policy mixes are the means through which fragmented government action can be overcome and cross-cutting policy problems can be addressed. This implies, in line with Marsden and Reardon (2017), that governments and researchers should pay more attention to procedural, governance-oriented policy instruments in the field of transport planning.

It should be noted, however, that this research had a very specific focus to allow for a more in-depth analysis. As a result, the study did not take into account, for instance, policy instruments for monitoring and evaluation, the role of national government, water boards, corporate and civil society stakeholders, or the influence of other land use and transport policy instruments not primarily aimed at achieving LUTI. Furthermore, this study adopted a qualitative approach to interaction. Therefore, it does not provide insights into the density of interactions and the strength of ties between policy actors. These limitations, however, provide promising avenues for future research. It would be interesting to extend the scope of this study in several ways, to find further verification of our findings by, for example, including national governments, looking outside the Dutch context and/or by taking into account other spatial sectors. Another interesting research topic would be a more in-depth comparison of different mixes based on their performance rather than their design. Finally, it would be interesting to see how sectoral land use or transport policy instruments interact with LUTI procedural instruments.

\section{Acknowledgments}

This research was supported financially by cooperation between the Faculty of Spatial Sciences of the University of Groningen and Rijkswaterstaat.

\section{Appendices}

Appendices A-G available at https:/www.jtlu.org/index.php/jtlu/article/view/1710 


\section{References}

Ansell, C. (2000). The networked polity: Regional development in Western Europe. Governance - An International Journal of Policy Administration and Institutions, 13(3), 303-333.

Arts, J., Filarski, R., Jeekel, H., \& Toussaint, B. (2016). Builders and planners: A history of land-use and infrastructure planning in the Netherlands. Delft, the Netherlands: Eburon Academic Publishers.

Arts, J., Hanekamp, T., \& Dijkstra, A. (2014). Integrating land-use and transport infrastructure planning: Towards adaptive and sustainable transport infrastructure. Paper presented at the Transport Research Arena, Paris.

Arts, J., Hanekamp, T., Linssen, R., \& Snippe, J. (2016). Benchmarking integrated infrastructure planning across Europe - Moving forward to vital infrastructure networks and urban regions. Transportation Research Procedia, 14, 303-312.

Bache, I., Flinders, M. V, \& Marsden, G. (2015). Multi-level governance and climate change: Insights from transport policy. United Kingdom: Rowman \& Littlefield International.

Banister, D. (2002). Transport planning, 2nd ed. London: Spon Press.

Banister, D. (2005). Unsustainable transport: City transport in the new century. London: Routledge. https://doi.org/10.4324/9780203003886

Banister, D., Anderton, K., Bonilla, D., Givoni, M. and Schwanen, T. (2011). Transportation and the environment. Annual Review of Environment and Resources, 36, 247-270.

Banister, D. \& Berechman, Y. (2001). Transport investment and the promotion of economic growth. Journal of Transport Geography, 9(3), 209-218.

Bemelmans-Videc, M. L., Rist, R. C., \& Vedung, E. O. (2011). Carrots, sticks, and sermons: Policy instruments and their evaluation. Piscataway, NJ: Transaction Publishers.

Bertolini, L. (2012). Integrating mobility and urban development agendas: A manifesto. Dis P-The Planning Review, 48(1), 16-26.

Bertolini, L., le Clercq, F. \& Kapoen, L. (2005). Sustainable accessibility: A conceptual framework to integrate transport and land use plan-making. Two test-applications in the Netherlands and a reflection on the way forward. Transport Policy, 12(3), 207-220. https://doi.org/10.1016/j.tranpol.2005.01.006

Bliemer, M. C. J., Mulley, C., \& Moutou, C. J. (Eds.). (2016). Handbook on transport and urban planning in the developed world. Cheltenham, UK: Edward Elgar Publishing.

Bressers, H. T. A., \& O'toole, L. J. (2005). Instrument selection and implementation in a networked context. In P. Eliadis, M. M. Hill, \& M. Howlett (Eds.), Designing government: From instruments to governance (pp. 132-153). London: McGill-Queen's University Press Montreal and Kingston.

Candel, J. J. L., \& Biesbroek, R. (2016). Toward a processual understanding of policy integration. Policy Sciences, 49(3), 211-231.

Capano, G., \& Howlett, M. (2019). Causal logics and mechanisms in policy design: How and why adopting a mechanistic perspective can improve policy design. Public Policy and Administration. https://doi.org/10.1177/0952076719827068

Cejudo, G. M., \& Michel, C. L. (2017). Addressing fragmented government action: Coordination, coherence, and integration. Policy Sciences, 50(4), 745-767.

Christensen, T., \& Lægreid, P. (2007). The whole-of-government approach to public sector reform. Public Administration Review, 67(6), 1059-1066.

Curtis, C. (2008). Planning for sustainable accessibility: The implementation challenge. Transport Policy, 15(2), 104-112.

Duffhues, J., \& Bertolini, L. (2016). From integrated aims to fragmented outcomes: Urban intensifica- 
tion and transportation planning in the Netherlands. Journal of Transport and Land Use, 9(3), 15-34.

Dunleavy, P., \& Hood, C. (1994). From old public administration to new public management. Public Money \& Management, 14(3), 9-16.

ECMT (2002). Implementing sustainable urban travel policies: Final report. Paris: OECD Publishing. https://doi.org/10.1787/9789282112892-en

Eddington, R. (2006). The Eddington transport study: Transport's role in sustaining the UK's productivity and competitiveness. Norwich, England: HM Treasury.

Elverding, C., Graeff, J. D., Ketting, N., Koeman, N., Ru, H. D., \& Scheltema, M. (2008). Sneller En Beter, Advies Commissie Versnelling Besluitvorming Infrastructurele Projecten. Retrieved from https://zoek.officielebekendmakingen.nl/kst-29385-18-b2.pdf

Ewing, R. and Cervero, R. (2001). Travel and the built environment: A synthesis. Transportation Research Record, 1780(1), 87-114.

Farrington, J., \& Farrington, C. (2005). Rural accessibility, social inclusion and social justice: Towards conceptualisation. Journal of Transport Geography, 13(1), 1-12.

Geerlings, H., \& Stead, D. (2003). The integration of land use planning, transport and environment in European policy and research. Transport Policy, 10(3), 187-196.

Gudmundsson, H., Hall, R.P., Marsden, G. \& Zietsman, J. (2015). Sustainable transportation: Indicators, frameworks, and performance management. Heidelberg, Germany: Springer.

Hatzopoulou, M., \& Miller, E. J. (2008). Institutional integration for sustainable transportation policy in Canada. Transport Policy, 15(3), 149-162.

Heeres, N. (2017). Toward area-oriented approaches in infrastructure planning: Development of national highway networks in a local spatial context (Doctoral dissertation). University of Groningen. Retrieved from https://www.rug.nl/research/portal/publications/towards-areaoriented-approaches-in-infrastructure-planning(927e294a-19fa-4966-8a5b-f0cfbc5c1f49)/export.html

Heeres, N., Tillema, T., \& Arts, J. (2012). Integration in Dutch planning of motorways: From "line" towards "area-oriented" approaches. Transport Policy, 24, 148-158.

Heeres, N., Tillema, T., \& Arts, J. (2016). Dealing with interrelatedness and fragmentation in road infrastructure planning: An analysis of integrated approaches throughout the planning process in the Netherlands. Planning Theory \& Practice, 17(3), 421-443.

Howlett, M. (2000). Managing the "hollow state": Procedural policy instruments and modern governance. Canadian Public Administration, 43(4), 412-431.

Howlett, M. (2014a). From the "old" to the "new" policy design: Design thinking beyond markets and collaborative governance. Policy Sciences, 47(3), 187-207.

Howlett, M. (2014b). Policy design: What, who, how and why? In C. Halpern, P. Lascoumes, and P. Le Galès (Eds.), Linstrumentation de l'action publique: Controverses, résistances, effets (pp. 281-316). Paris: Presses de Sciences Po.

Howlett, M. (2018). The contexts and components of policy design. In M. Howlett \& I. Mukherjee (Eds.), Routledge handbook of policy design (pp. 20-33). New York: Routledge.

Howlett, M., \& Lejano, R. P. (2013). Tales from the crypt: The rise and fall (and rebirth?) of policy design. Administration \& Society, 45(3), 357-381.

Howlett, M., \& Rayner, J. (2004). (Not so) "smart regulation"? Canadian shellfish aquaculture policy and the evolution of instrument choice for industrial development. Marine Policy, 28(2), 171-184.

Howlett, M., \& Rayner, J. (2007). Design principles for policy mixes: Cohesion and coherence in "new governance arrangements." Policy and Society, 26(4), 1-18.

Howlett, M., \& Rayner, J. (2018). Coherence, congruence and consistency in policy mixes. In M. Howlett \& I. Mukherjee (Eds.), Routledge handbook of policy design (pp. 389-403). New York: Rout- 
ledge.

Howlett, M., \& del Rio, P. (2015). The parameters of policy portfolios: Verticality and horizontality in design spaces and their consequences for policy mix formulation. Environment and Planning C: Government and Policy, 33(5), 1233-1245.

Hull, A. (2008). Policy integration: What will it take to achieve more sustainable transport solutions in cities? Transport Policy, 15(2), 94-103.

Hull, A. (2010). Transport matters: Integrated approaches to planning city-regions. New York: Routledge.

ITF. (2019). Improving transport planning and investment through the use of accessibility indicators. In International Transport Forum Policy Papers. Paris: OECD Publishing.

Jochim, A. E., \& May, P. J. (2010). Beyond subsystems: Policy regimes and governance. Policy Studies Journal, 38(2), 303-327.

Johansson, F., Tornberg, P., \& Fernström, A. (2018). A function-oriented approach to transport planning in Sweden: Limits and possibilities from a policy perspective. Transport Policy, 63, 30-38.

Jones, P., \& Lucas, K. (2000). Integrating transport into “joined-up” policy appraisal. Transport Policy, 7(3), 185-193.

Jordan, A., \& Lenschow, A. (2010). Environmental policy integration: A state of the art review. Environmental Policy and Governance, 20(3), 147-158.

Jordan, A., Wurzel, R. K. W., \& Zito, A. (2005). The rise of "new" policy instruments in comparative perspective: Has governance eclipsed government? Political Studies, 53(3), 477-496.

Keast, R., Brown, K., \& Mandell, M. (2007). Getting the right mix: Unpacking integration meanings and strategies. International Public Management Journal, 10(1), 9-33.

Kelly, E. D. (1994).The transportation land-use link. Journal of Planning Literature, 9(2), 128-145.

Klijn, E. H., \& Koppenjan, J. (2016). Governance networks in the public sector. New York: Routledge.

Kooiman, J. (2003). Governing as governance. Thousand Oaks, CA: Sage Publishing.

Lahdenperä, P. (2012). Making sense of the multi-party contractual arrangements of project partnering, project alliancing and integrated project delivery. Construction Management and Economics, 30(1), 57-79.

Lascoumes, P., \& Le Gales, P. (2007). Introduction: Understanding public policy through its instruments-From the nature of instruments to the sociology of public policy instrumentation. Governance, 20(1), 1-21. https://doi.org/10.1111/j.1468-0491.2007.00342.x

Lenferink, S., Tillema, T., \& Arts, J. (2013). Towards sustainable infrastructure development through integrated contracts: Experiences with inclusiveness in Dutch infrastructure projects. International Journal of Project Management, 31(4), 615-627.

Leroy, P., \& Arts, B. (2006). Institutional dynamics in environmental governance. In Institutional Dynamics in Environmental Governance (pp. 1-19). New York: Springer.

Lieu, J., Spyridaki, A. N., Alvarez-Tinoco, R., van der Gaast, W., Tuerk, A., \& van Vliet, O. (2018). Evaluating consistency in environmental policy mixes through policy, stakeholder, and contextual interactions. Sustainability, 10(6), 1896. https://doi.org/10.3390/su10061896

Macario, R., Carvalho, D., \& Fermisson, J. (2005). Achieving sustainable transport and land use with integrated policies. In S. Syngellakis (Ed.), WIT Transactions on the built environment. Southampton, UK: WIT Press.

Marsden, G., \& Reardon, L. (2017). Questions of governance: Rethinking the study of transportation policy. Transportation Research Part A: Policy and Practice, 101, 238-251.

Marsden, G. R., \& May, A. D. (2006). Do institutional arrangements make a difference to transport policy and implementation? Lessons for Britain. Environment and Planning C: Government and Policy, 24(5), 771-789. 
Marshall, S., \& Banister, D. (2007). Land use and transport: European research towards integrated policies. Bingley, UK: Emerald Group Publishing Limited.

May, A. D., Kelly, C., Shepherd, S., \& Jopson, A. (2012). An option generation tool for potential urban transport policy packages. Transport Policy, 20, 162-173.

May, T., \& Crass, M. (2007). Sustainability in transport: Implications for policy makers. Transportation Research Record, 2017(1), 1-9.

Mitchell, R .B., \& Rapkin, C. (1954). Urban traffic: A function of land use. New York: Columbia University Press.

Moeckel, R., Llorca Garcia, C., Moreno Chou, A. T., \& Okrah, M. B. (2018). Trends in integrated land use/transport modeling: An evaluation of the state of the art. Journal of Transport and Land Use, 11(1) 463-476.

Mu, R., \& de Jong, M. (2016). A network governance approach to transit-oriented development: Integrating urban transport and land-use policies in Urumqi, China. Transport Policy, 52, 55-63.

OECD (2014). OECD Territorial reviews: Netherlands 2014. Paris: OECD Publishing. https://doi. org/10.1787/9789264209527-en

Overijssel. (2017). Catalogus Gebiedskenmerken. Provincie Overijssel, Zwolle.

Papa, E., Silva, C., te Brömmelstroet, M., \& Hull, A. (2016). Accessibility instruments for planning practice: A review of European experiences. Journal of Transport and Land Use, 9(3), 57-75.

Peters, B. G. (2015). Pursuing horizontal management. Lawrence, KS: University Press of Kansas.

Peters, B. G. (2018a). Policy problems and policy design. Cheltenham, England: Edward Elgar Publishing.

Peters, B. G. (2018b). The challenge of policy coordination. Policy Design and Practice, 1(1), 1-11.

Peters, B. G., Capano, G., Howlett, M., Mukherjee, I., Chou, M.-H., \& Ravinet, P. (2018). Designing for policy effectiveness: Defining and understanding a concept. Cambridge, England: Cambridge University Press.

Pfeffer, J., \& Salancik, G. R. (2003). The external control of organizations: A resource dependence perspective. Stanford, CA: Stanford University Press.

Pollitt, C., \& Bouckaert, G. (2011). Public management reform: A comparative analysis - New public management, governance, and the neo-weberian state. Oxford, England: Oxford Univeristy Press.

Poppelaars, C. (2007). Resource exchange in urban governance: On the means that matter. Urban Affairs Review, 43(1), 3-27.

Rayner, J. \& Howlett, M. (2009). Introduction: Understanding integrated policy strategies and their evolution. Policy and Society, 28(2), 99-109.

Rli. (2016). Closer and faster: Opportunities for better accessiblity in urban regions. The Hague: Council for the Living Environment and Infrastructure.

Rogge, K. S., \& Reichardt, K. (2016). Policy mixes for sustainability transitions: An extended concept and framework for analysis. Research Policy, 45(8), 1620-1635.

Salamon, L. M. (2000). The new governance and the tools of public action: An introduction. Fordham Urb. $L J, 28,1611-1674$.

Silva, C., Bertolini, L., te Brömmelstroet, M., Milakis, D., \& Papa, E. (2017). Accessibility instruments in planning practice: Bridging the implementation gap. Transport Policy, 53(9), 135-145.

Stead, D. (2008). Institutional aspects of integrating transport, environment and health policies. Transport Policy, 15(3), 139-148.

Stead, D. (2016). Key research themes on governance and sustainable urban mobility. International Journal of Sustainable Transportation, 10(1), 40-48.

Stead, D., Geerlings, H., \& Meijers, E. (Eds.). (2004). Policy integration in practice: The integration of land-use planning, transport and environmental policy making in Denmark, England and Germany. 
Delft: Delft University Press.

Stead, D., \& Marshall, S. (2001). The relationships between urban form and travel patterns. An international review and evaluation. European Journal of Transport and Infrastructure Research, 1(2). Retrieved from https://journals.open.tudelft.nl/index.php/ejtir/article/view/3497

Stead, D., \& Meijers, E. (2009). Spatial planning and policy integration: Concepts, facilitators and inhibitors. Planning Theory \& Practice, 10(3), 317-332.

Straatemeier, T. (2008). How to plan for regional accessibility? Transport Policy, 15(2), 127-137.

Switzer, A., Bertolini, L. \& Grin, J. (2013). Transitions of mobility systems in urban regions: A heuristic framework. Journal of Environmental Policy \& Planning, 15(2), 141-160.

te Brömmelstroet, M. (2010). Equip the warrior instead of manning the equipment: Land use and transport planning support in the Netherlands. Journal of Transport and Land Use, 3(1), 25-41.

te Brömmelstroet, M., \& Bertolini, L. (2010). Integrating land use and transport knowledge in strategymaking. Transportation, 37(1), 85-104.

Torfing, J. (2012). Interactive governance: Advancing the paradigm. Oxford, England: Oxford University Press on Demand.

Tornberg, P., \& Odhage, J. (2018). Making transport planning more collaborative? The case of strategic choice of measures in Swedish transport planning. Transportation Research Part A: Policy and Practice, 118, 416-429.

Tosun, J., \& Lang, A. (2017). Policy integration: Mapping the different concepts. Policy Studies, 38(6), 553-570.

Trein, P., Meyer, I., \& Maggetti, M. (2019). The integration and coordination of public policies: A systematic comparative review. Journal of Comparative Policy Analysis: Research and Practice, 21(4), 332-349.

UN-Habitat (2013). Planning and design for sustainable urban mobility: Global report on human settlements 2013. New York: Routledge.

V\&W. (1977). Structuurschema Verkeer En Vervoer - Deel a: Beleidsvoornemen, Ministerie van Verkeer en Waterstaat.

van Geet, M. T., Lenferink, S., Arts, J., \& Leendertse, W. (2019). Understanding the ongoing struggle for land use and transport integration: Institutional incongruence in the Dutch national planning process. Transport Policy, 73, 84-100.

van Geet, M. T., Lenferink, S., \& Leendertse, W. (2019). Policy design dynamics: Fitting goals and instruments in transport infrastructure planning in the Netherlands. Policy Design and Practice, 2(4), 324-358.

van Wee, B., Annema, J.A., \& Banister, D. (2013). The transport system and transport policy: An introduction. Cheltenham, UK, and Northhampton, MA: Edward Elgar.

Wegener, M., \& Fürst, F. (1999). Land-use transport interaction: State of the art. Reports from the Institute for Spatial Planning 46. Dortmund, Germany: Universität Dortmund - Fakultät Raumplanung. Yin, R. K. (2003). Case study research: Design and methods. Thousand Oaks, CA: Sage Publishing. 